\title{
SEDIMEN DAN MANFAATNYA
}

\section{Oleh \\ Helfinalis ${ }^{1}$}

\section{ABSTRACT}

SEDIMENT AND ITS BENEFITS. Sediment deposition is a form of compact material that accumulates on the surface or near the surface of the earth, under conditions of low pressure and temperature. Sediment is generally a product of old rock destruction which is transported and distributed by water or wind currents. Sediments are the result of chemical or biochemical precipitation of the solution. Learning the distribution of sediment on the seabed is desperately needed and very useful, for the initial phase to lay the wire and pipe lines on the sea, consider topography of sea (bathimetry), sedimentary texture and ocean currents. Clays are considered unfavorable for the laying of construction pole as a result of clay having a high volume change potential. Clay will undergo expansion when water increases and shrinkage occurs when the water content is less. Rock sediments of sand and limestone are useful for building materials.

\section{PENDAHULUAN}

Wilayah pesisir adalah merupakan daerah yang masih dipengaruhi oleh proses-proses yang terjadi di daratan, seperti material sedimen yang dibawa bersama air sungai, dan tersedimentasi di daerah pesisir (Anonim, 2014). Di Amerika Serikat, istilah sedimentasi umumnya digunakan untuk menamakan ilmu yang mempelajari proses pengakumulasian sedimen, khususnya endapanyang asalnya merupakan partikelpartikel padat dalam suatu fluida. Istilah sedimentologi untuk menamakan ilmu yang mempelajari segala aspek sedimen dan batuan. Sedimentologi adalah ilmu yang mempelajari pembentukan lapisan tanah di suatu tempat yang diakibatkan oleh perpindahan batuan yang terbentuk akibat dari pelapukan dari satu tempat yang terendapkan di

\footnotetext{
1) Pusat Penelitian Oseanografi-LIPI
}

tempat lain. Kemudian hasil pelapukan tersebut dipindahkan oleh air dan angin sebagai pengangkut yang utama. Sedimen tersebut apabila mengeras akan menjadi batu sedimen, contohnya adalah sedimentasi yang terjadi di delta sungai dan daerah sekitar gunung berapi. Ilmu ini berkaitan erat dengan pembentukan bahan galian, seperti batubara, minyak bumi, emas, dan perak. Petrologi sedimen adalah cabang petrologi yang membahas batuan sedimen, terutama pemeriannya (deskripsi, atau penguraian unsur-unsur) (Anonim, 2012).

Sedimen adalah partikel hasil dari pelapukan batuan, material biologi, endapan kimia, debu, material sisa tumbuhan dan daun (Bent et al., 2001). Endapan sedimen adalah material padat yang terakumulasi di permukaan bumi atau dekat permukaan bumi, pada kondisi 
tekanan dan temperatur yang rendah. Endapan sedimen umumnya merupakan produk penghancuran batuan tua yang kemudian diangkut dan didistribusikan oleh arus atau angin. Sebagian sedimen merupakan hasil presipitasi kimia atau biokimia dari larutan. Ada beberapa jenis sedimen yang tidak berasal dari hancuran batuan tua, misalnya batubara yang pada dasarnya merupakan residu organik yang berasal dari tumbuhan serta sedimen vulkanogenik yang berasal dari material hasil letusan gunung api. Sedimen yang tidak berasal dari batuan tua umumnya memiliki ukuran yang relatif kecil dan jarang ditemukan. Selain itu, masih ada material lain yang digolongkan ke dalam batuan sedimen, namun sangat jarang ditemukan, yaitu endapan material kosmik yang berasal dari ruang angkasa (Anonim, 2012).

\section{MATERIAL SEDIMEN}

Sifat material sedimen sangat bervariasi dari sisi origin, ukuran, bentuk dan komposisi. Material tersebut dapat berasal dari pelapukan batuan yang lebih tua, hasil erupsi gunung api, ataupun organisme seperti filamen mikroba yang terbentuk dari kalsium karbonat baik dalam bentuk utuh atau berupa pecahan cangkang, terumbu karang, tulang dan sisa-sisa tanaman. Pengendapan langsung larutan mineral dalam air juga merupakan sumber material sedimen pada kondisi tertentu. Proses transportasi material sedimen ke lokasi pengendapan dipengaruhi oleh gaya gravitasi, air, udara, es, dan aktivitas organisme/biologi. Sebagian besar akumulasi material sedimen dipengaruhi oleh unsur kimia, suhu, dan karakter biologinya. Proses transportasi dan pengendapan dapat diinterpretasikan dari karakteristik tiaptiap lapisan batuan sedimen, baik dari struktur, ukuran, bentuk, dan distribusi material sedimennya (Anonim, 2015).

Pada umumnya, sedimen yang terbawa adalah sedimen yang melayang atau kandungan total suspended solid (TSS) di kolom air. Sedimen yang melayang tersebut dapat memengaruhi cahaya matahari menembus air laut. Konsentrasi total suspended solid kolom air laut yang rendah menyebabkan daya tembus sinar matahari lebih besar, dan sebaliknya apabila konsentrasi total suspended solid tinggi maka cahaya tidak jauh menembus kolum air laut (Dunton et al., 2003). Sebaliknya, apabila konsentrasi total suspended solid pada kolom air kecil maka produktivitas tahunan di kolom air juga rendah (Best et al., 2001; Murphy, 2007). Nilai Baku Mutu Kementerian Lingkungan hidup untuk total suspended solid di kawasan terumbu karang adalah sebesar $20 \mathrm{mgl} /$ liter (Anonim, 2004).

\section{TEKSTUR SEDIMEN}

Wentworth (1922), telah mengklasifikasikan butiran sedimen berdasarkan ukuran diameter butir, antara lain sebagai berikut 
Tabel 1. Klasifikasi butiran sedimen berdasarkan ukuran butir

\begin{tabular}{|l|l|l|}
\hline No. & Butiran sedimen & Ukuran butir (mm) \\
\hline 1. & Kerikil & $2-4$ \\
\hline 2. & Pasir sangat kasar & $1-2$ \\
& Pasir kasar & $0.5-1$ \\
& Pasir sedang & $0.25-0.5$ \\
& Pasir halus, & $0.125-0.25$ \\
& Pasir sangat halus & $0.063-0.12$ \\
\hline 3. & Lanau & $0.043-0.063$ \\
\hline 4. & Lempung & $0.002-0.04$ \\
\hline
\end{tabular}

Menurut Purnomo (2011), kerikil dan pasir merupakan material yang berbutir kasar dan tidak kohesif, sedangkan lanau dan lempung adalah berbutir halus dan kohesif.

\section{STRUKTUR BATUAN SEDIMEN}

Pengendapan sedimen dalam kurun waktu yang lama akan membentuk lapisan endapan yang tebal, dan selama proses pengendapan membentuk bermacam-macam tipe struktur. Tipe struktur tersebut terbentuk tergantung dari pergerakan massa air. Butiran halus mengendap di energi massa air rendah dan butiran kasar pada aliran massa yang berenergi tinggi (Anonim, 2018).

\section{Bentuk - Bentuk Struktur Sedimen}

Flaser bedding adalah endapan pasir yang dominan yang disisipi oleh lensa lumpur. Wavy laminasi adalah pasir yang berselang seling dengan lempung atau lumpur. Lenticuler laminasi adalah lempung atau lumpur yang dominan disisipi oleh lensa pasir (Anonim, 2012a).

\section{Komposisi Sedimen}

Batuan sedimen berbeda dengan batuan beku, karena batuan sedimen memiliki komposisi yang lebih bervariasi, meskipun ada beberapa diantaranya yang memiliki komposisi sangat sederhana. Konsentrasi unsur-unsur kimia di kerak bumi terutama ditemukan dalam batuan sedimen. Sebagian konsentrat itu merupakan produk pembersihan dan penggabungan residu pelapukan batuan tua, misalnya pasir kuarsa yang dapat mengandung silika lebih dari 99\%. Sebagian konsentrat lain merupakan produk dari proses-proses kimia dan biokimia selektif, contohnya adalah batu gamping kalsium-tinggi (mengandung $\mathrm{CaCO}_{3}>99 \%$ ), garam batu, dan gipsum (Anonim, 2012). 


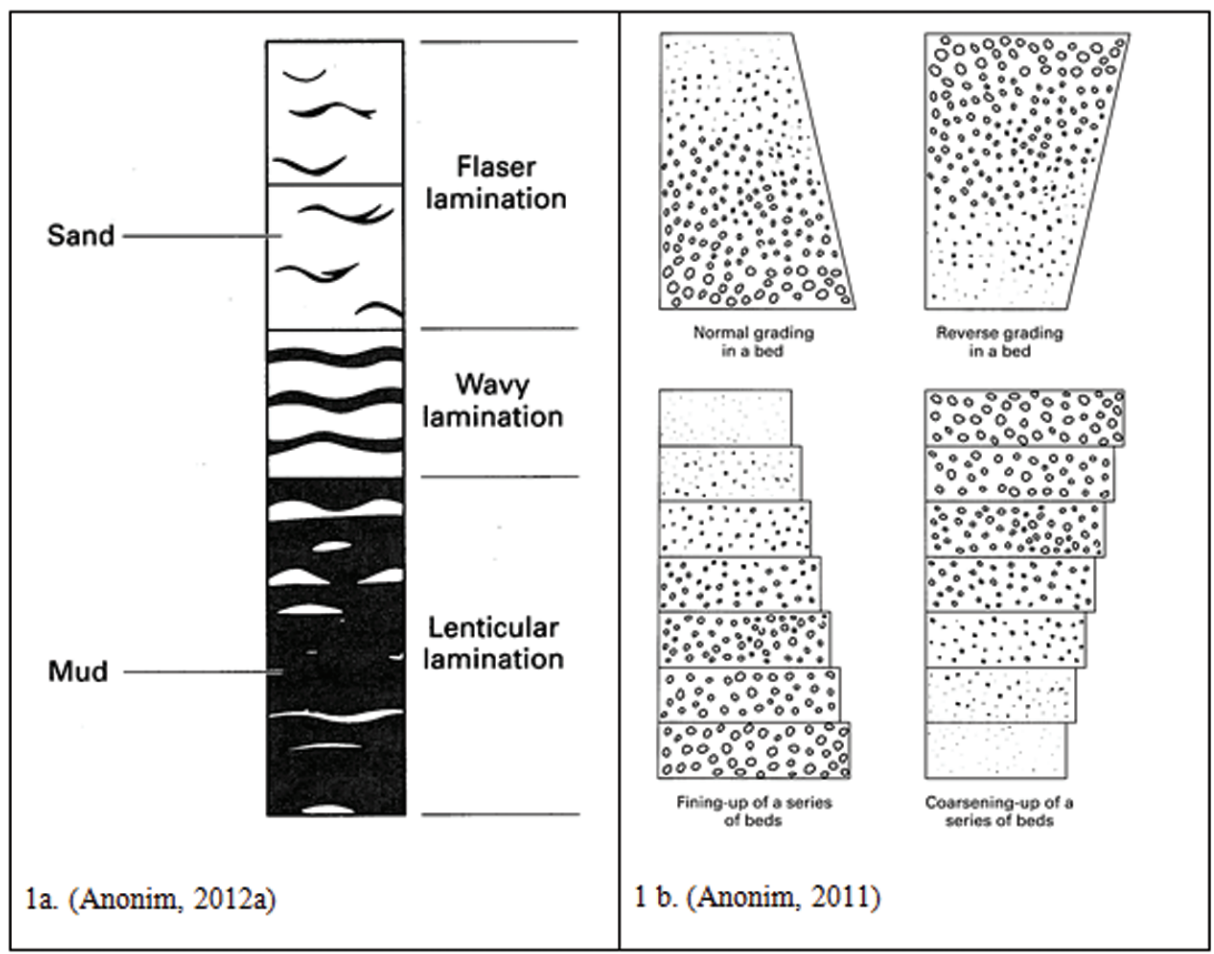

Gambar 1. Bentuk struktur sedimen yang di endapkan oleh proses turbidity current (a) dan Turbidity current yang membentuk tipe gradasi normal akibat kecepatan arus mengecil dan membentuk tipe gradasi terbalik, butiran kasar di atas dan yang halus di bawah (b).

\section{MANFAAT STUDI SEDIMEN DI DASAR PERAIRAN}

Sebaran tekstur sedimen di dasar laut sangat diperlukan dan sangat bermanfaat untuk tahap kajian awal dalam perencanaan peletakan jalur kabel dan pipa dasar laut. Hal tersebut harus mempertimbangkan bentuk dari topografi dasar laut (batimetri), tekstur sedimen dan arus laut. Untuk peletakan kabel dan pipa dasar laut sebaiknya dipilih topografi dasar laut yang datar atau landai dengan tekstur sedimen pasir lumpuran, agar tidak mengalami perubahan posisi sedangkan sedimen berlumpur tidak disarankan untuk memasang bentangan kabel, karena kabel akan cepat melengkung sehingga mengalami kerusakan.

Variasi warna lempung berwarna coklat juga merefleksikan kandungan senyawa organik. Warna coklat mengandung karbon organik lebih kecil dari $0,3 \%$, warna abu-abu kehijauan mengandung karbon organik 1-2 \% (Hèuneke \& Mulder, 2011). Sebaliknya, pasir lumpuran sangat tepat untuk konstruksi rig lepas pantai, karena tiang pancang akan lebih stabil.

Dalam hal rancang bangun juga diperlukan data California bearing 
ratio (CBR) atau pemadatan sedimen (tanah) atau perbandingan antara beban penetrasi suatu lapisan tanah atau perkerasan terhadap bahan standar dengan kedalaman. Dalam konstruksi bangunan sipil, nilai CBR, PI (plasticity index) dan sudut geser tanah sangat berpengaruh dalam perencanaan suatu bangunan, terutama dalam perencanaan jalan, landas pacu lapangan terbang, pada pembangunan tanggul dan serta kontruksi timbunan lainnya. Lempung dianggap kurang baik untuk peletakan tiang-tiang konstruksi, karena lempung mempunyai potensi perubahan volume yang cukup tinggi, yaitu mempunyai rata-rata Plastic Index (PI) >20. Tanah lempung akan mengalami pemuaian ketika air bertambah referensinya. Penyusutan terjadi pada saat kadar air berkurang dari angka referensinya sampai batas susut (Purnomo, 2011).

Sedimen klastika memiliki porositas dan permeabilitas tertentu. Porositas dan permeabilitas memungkinkan sedimen klastika untuk menyimpan dan mengalirkan fluida. Batuan sedimen merupakan reservoar penting untuk gas alam, minyak bumi, air artesis, dan berbagai larutan garam. Porositas awal dari suatu jenis batuan sedimen cukup tinggi, namun kemudian nilai porositas itu menurun, seiring terjadinya presipitasi mineral dalam ruang pori. Pasir dan lumpur terbentuk di daratan, terangkut melalui sungai, kemudian terendapkan di laut (Anonim, 2012).

Tidak semua proses pembentukan sedimen dapat dilihat secara langsung, contohnya proses-proses diagenetik dan arus turbid yang mengangkut dan mengendapkan sedimen serta pembentukan batuan kimia Oleh karena itu, untuk mengetahui batuan beku, batuan metamorf dan asal-usul batuan sedimen harus direkonstruksikan dari rekaman geologi, yaitu pengaruh yang dihasilkan oleh proses-proses yang bekerja dalam waktu yang lama seperti tekstur, struktur, dan mineralogi endapan. Oleh karena itu, para ahli petrologi mengemban tugas yang sangat berat, yakni mengamati rekamangeologi, kemudian membaca untuk mengungkapkan misteri yang terkandung didalamnya (Anonim, 2012).

\section{NILAI EKONOMIS DARI SEDIMEN}

Menurut data statistik yang ada saat ini, sekitar 85-90\% produk mineral tahunan berasal dari mineral sedimenter dan endapan biji. Kenyataan itu sudah cukup menjadi alasan untuk mempelajari sedimentologi. Manfaat ekonomis penting dari sedimen, antara lain

1. mengandung bahan bakar fosil (migas) serta air terkandung.

2. Merupakan material bahan bakar, misalnya batubara dan serpih minyak (oil shale).

3. Merupakan material baku industri keramik, semen portland, serta bahan bangunan.

4. Tempat dimana mineral logam dan nonlogam terakumulasi.

Selain itu sedimentologi perlu dipahami terutama pada bagian proses pembentukan, pergerakan, dan pengendapan sedimen. Hal ini sangat 
penting dalam dunia ilmu pengetahuan geomorfologi, untuk memahami dan mengantisipasi fenomena erosi pantai, pembangunan pelabuhan, manajemen dataran banjir, dan erosi tanah (Anonim, 2012).

\section{PENUTUP}

Endapan sedimen merupakan batuan yang tertransportasi dari hasil material kompak yang terakumulasi di permukaan bumi atau merupakan produk penghancuran batuan tua yang kemudian diangkut dan didistribusikan oleh arus atau angin. Sebagian sedimen merupakan hasil presipitasi kimia atau biokimia dari larutan. Sebaran tekstur sedimen di dasar laut sangat bermanfaat untuk dipelajari, terutama untuk tahap kajian awal peletakan jalur kabel dan pipa di dasar laut yang harus mempertimbangkan bentuk dari topografi dasar laut (batimetri), tekstur sedimen dan arus laut.

\section{DAFTAR PUSTAKA}

Anonim. 2004. Pedoman penetapan baku mutu lingkungan. Kantor Menteri Negara Kependudukan Lingkungan Hidup 2004. Keputusan Menteri Negara Kependudukan dan Lingkungan Hidup. Kep-51/ MENEGLH/2004. Sekretariat Negara, Jakarta. 10 pp

Anonim. 2011. http://geofact.blogspot. co.id/2011/01/proses transportasi-dan-struktur.html. Diakses tanggal 1 September 2011
Anonim. 2012. https://wingmanarrows. wordpress.com/2012/03/07/ batuan-sedimen-pettyjohn1975-bab-i-pendahuluan/. Diakses tanggal 7 Maret 2012

Anonim. 2012a. http://zonageologi. blogspot.co.id/2012/07/ struktur-sedimen.html. Diakses tanggal 1 Juli 2012

Anonim. 2014. Potensi dan persebaran sumber daya laut di Indonesia. http://ipsgampang.blogspot. co.id/2014/08/potensi-danpersebaran-sumber-dayalaut 14.html. Diakses tanggal 14 Agustus 2014

Anonim. 2015. https://smiagiung. blogspot.co.id/2014/08/ pengenalan-sedimentologidan-stratigrafi.html. Diakses tanggal 23 Agustus 2014

Anonim. 2018. http://www.academia. edu/11144273/Mekanisme Transportasi_Sedimentasi. Diakses tanggal 13 Februari 2018

Bent, G. C., J. R. Gray, K. P. Smith, and D. Glysson, 2001. A Synopsis of technical issues for monitoring sediment in highway and urban runoff. USGS, OFR 00-497. 497pp

Best, E. P. H., C. P. Buzzelli, S. M. Bartell, R. L. Wetzel, W. A. Boyd, R. D. Doyle, and K. R. Campbell. 2001. Modeling submersed macrophyte growth in relation to underwater light 
climate : Modelling approaches and application potential. Hydrobiologia 444: 43-70

Dunton, K., A. Burd, D. Funk and R. Maffioneffione. 2003. Linking water turbidity and total suspended solids loading to kelp productivity within the stefannson sound boulder path. Report Prepared by Craig Aumack. MMS Alaska Environmental Studies Program. $86 \mathrm{pp}$

Hèuneke, H. and T. Mulder. 2011. Deepsea sediments. Elsevier: 849 pp
Murphy. S. 2007. General Information on Solids. City of Boulder/USGS Water Quality. Monitoring. http://bcn.boulder.co.us/basin/ data/BACT/info/TOTAL SUSPENDED SOLID.html. Mei 23. 2007

Purnomo M. 2011. Korelasi antara CBR, PI dan kuat geser tanah lempung. Jurnal teknik sipil dan perencanaan (1) 13: 81-90

Wentworth. C.K. 1922. A Scale of grade and class term for clastic sediment. Jour. Geol. 30 : 337 $-392$ 